\title{
Beta-Adrenoceptor Modulation in a Case of Pure Autonomic Failure
}

\author{
Sergio Perna, Rocco Leone, Maria Jussie Farace, Vincenzo Brescia-Morra, \\ Giuseppe Campanella and Gregorio Brevetti
}

\begin{abstract}
In a patient with pure autonomic failure, exercise did not modify beta-adrenoceptor density, probably due to an insufficient increase in plasma catecholamines. Isoproterenol infusion increased the number of beta-adrenoceptor by only $17 \%$. Since in control subjects an increased beta-adrenoceptor level was found, following both physical stress and isoproterenol infusion, we suggest that the lack of increased beta-adrenoceptor levels may contribute to the poor circulatory adjustments observed in autonomic dysfunction during activities involving the sympathetic nervous system.
\end{abstract}

\begin{abstract}
RÉSUMÉ: Modulation du récepteur bêta-adrénergique chez un cas de défaillance neuro-végétative. Chez un patient avec défaillance neuro-végétative pure, l'exercice n'a pas modifié la densité des récepteurs bêta-adrénergiques, ce qui va avec une augmentation insuffisante des catécholamines plasmatiques. L'infusion d'isoprotérénol n'a augmenté le nombre de récepteurs bêta-adrénergiques que de $17 \%$. Comme on a trouvé une augmentation du nombre des récepteurs bêta-adrénergiques chez les sujets contrôles, tant suite à un stress physique qu'à une infusion d'isoprotérénol, nous suggérons que l'absence d'augmentation des récepteurs bêta-adrénergiques peut contribuer au peu d'ajustement circulatoire observé dans la dysfonction neuro-végétative pendant les activités impliquant le système nerveux sympathique.
\end{abstract}

Can. J. Neurol. Sci. 1992; 19: 80-83

Primary autonomic dysfunction may present with a wide range of clinical and pathological features. Although there are many problems with classifying these syndromes, a general classification of primary autonomic failure recognizes three groups of patients. ${ }^{\prime}$ In the first, autonomic failure occurs as a pure form, without any other neurological signs; in the second and third groups, two quite different degenerations of the nervous system are associated: Parkinson's disease and multiple system atrophy (MSA), respectively. Although it must be recognized that pure autonomic failure may eventually come to be associated either with Parkinson's disease or MSA, it is likely that the pathologic process differs significantly in pure autonomic failure (and probably in autonomic failure with Parkinson's disease) from that in autonomic failure with MSA. ${ }^{1}$ In pure autonomic failure, there appears to be an additional loss of ganglionic neurons ${ }^{2}$ which are relatively intact in MSA. The hypothesis that one of the lesions in pure autonomic failure is more distal accords with the evidence that 1) in general, plasma norepinephrine levels are lower in pure autonomic failure than in autonomic failure with $\mathrm{MSA}^{3}$ and 2) patients with MSA have normal norepinephrine release and blood pressure increases in response to indirectly acting sympathomimetic amines, while these drugs are ineffective in raising both norepinephrine levels and blood pressure in patients with pure autonomic dysfunction. ${ }^{3}$ In all conditions of autonomic dysfunction, plasma levels of catecholamines do not increase during activities that normally induce sympathetic stimulation, ${ }^{4}$ which accounts for the incapacity of affected individuals to adapt blood pressure and heart rate to normal environmental stress. Severe hypotension, unaccompanied by compensatory reflex tachycardia, affects patients with autonomic insufficiency when they stand or perform an exercise. ${ }^{5}$

Patients with autonomic dysfunction also show increased alpha- and beta-adrenoceptor responsiveness. ${ }^{6}$ In particular, their responsiveness to the chronotropic and the pressor effect of isoproterenol has been found to be 6- and 17-fold higher, respectively, than that of normal subjects. ${ }^{6}$ This denervation supersensitivity may be a consequence of enhanced end-organ beta-adrenoceptor density, which is known to be negatively correlated with the ambient levels of catecholamines. ${ }^{7}$ Indeed, in a patient with autonomic dysfunction, Huy and Connolly found that, in keeping with the low plasma catecholamines, resting lymphocyte beta-adrenoceptor density was more than twice normal levels. ${ }^{8}$ Dysautonomic patients also show an approximately sevenfold increase in alphaadrenoceptor number on blood platelets, when compared to normal subjects. ${ }^{9}$ Teleologically, these increases in the adrenoceptor population can be viewed as an adaptive response to maximize the effect of reduced noradrenaline release.

\footnotetext{
From the Department of Medicine and Neurological Clinic, 2nd Medical School, University of Naples, Naples, Italy

Received April 11, 1991. Accepted in final form August 23, 1991

Reprint requests to: Sergio Perna, Via Principati 17, 84100 Salerno, Italy
} 
The present study was designed to investigate the effect of physiologic and pharmacologic sympathetic stimulation on beta-adrenoceptor populations in autonomic dysfunction. Accordingly, in a patient with pure autonomic insufficiency, changes in beta-adrenoceptor density were assessed following exercise and isoproterenol infusion.

\section{Patient and Methods}

The patient was a 58-year-old man hospitalized because of orthostatic hypotension. On admission, his systemic supine arterial pressure was $160 / 105 \mathrm{mmHg}$, while, on standing it fell to $90 / 70 \mathrm{mmHg}$. Clinical and electrocardiographic findings did not indicate any cardiac abnormality. The patient did not show evidence of amyloidosis, diabetes, or other disorders associated with secondary orthostatic hypotension. The patient became aware of impotentia erigendi four years before the study. No signs of bladder or rectal dysfunction were present. Rigidity, tremor and loss of associated movements were absent. Plasma norepinephrine, which was $96 \mathrm{pg} / \mathrm{ml}$ in the supine position, did not change with the assumption of the erect position. Plasma epinephrine was undetectable in both supine and standing positions. Tests of autonomic function, including sweat test, hyperventilation, cold pressure test, and mental arithmetic test were performed according to Ibrahim. ${ }^{10}$ The low resting levels of plasma catecholamines and the absence of symptoms of MSA led to a diagnosis of pure autonomic failure. The patient was drug-free at the time of the study.

After informed consent was obtained, a catheter was placed into an antecubital vein and the patient rested recumbent for 30 minutes before the first blood sample was taken. The patient then performed bicycle exercise while in a supine position at 70 watts until exhaustion. Blood samples were taken under control conditions, at the end of the exercise, and 1 and 4 minutes after the cessation of exercise, during the recovery period. The next day, the patient received isoproterenol by intravenous infusion, at a dose of $2 \mu \mathrm{g} / \mathrm{min}$, for 30 minutes. Blood samples were obtained after 30 minutes of supine rest, under control conditions, and at the end of infusion. Heart rate was determined by electrocardiogram and blood pressure by auscultation.

The control group consisted of 10 normal subjects matched to the patient with respect to age and sex. Six of them underwent supine bicycle exercise at 70 watts until exhaustion. The others received isoproterenol at the same dose as the patient. Lymphocytes were obtained according to the method of Boyum. ${ }^{11}$ Beta-adrenoceptor density was measured from the binding of the radioligand $3 \mathrm{H}$-dihydroalprenolol, as previously described. ${ }^{12}$

Plasma catecholamines were measured by cation-exchange high performance liquid chromatography with electrochemical detection. ${ }^{13}$ Both beta-adrenoceptor binding and plasma catecholamine assay were performed in duplicate. In both patient and normal individuals, history, physical examination and laboratory tests excluded the presence of any condition known to affect plasma levels of catecholamines and beta-adrenoceptor number. Exercise- and isoproterenol-induced changes in the var- ious parameters measured in the control group were statistically evaluated by the analysis of variance for repeated measures and the $t$ test for paired samples.

\section{RESULTS}

Tests of autonomic function indicated that in our patient the lesion in the baroreflex arc was most probably localized in the efferent sympathetic pathway. Indeed, both cold pressure and mental arithmetic tests induced an abnormal reduction in arterial blood pressure from the control value of $150 / 100$ to $120 / 80$ and $130 / 90 \mathrm{mmHg}$, respectively. On the contrary, a normal reduction in arterial blood pressure from $160 / 100$ to $140 / 90$ was recorded during hyperventilation. This indicates intact vasomotor centre responsiveness. A lesion in efferent adrenergic fibers was confirmed by impaired reflex sweating in response to hot environmental temperature.

Table 1 reports the effect of exercise testing on plasma catecholamines, blood pressure and heart rate. In the patient, venous plasma norepinephrine increased slightly from 96 to $113 \mathrm{pg} / \mathrm{ml}$, at peak exercise. Epinephrine, undetectable under resting conditions, was $10 \mathrm{pg} / \mathrm{ml}$ at peak exercise. During recovery, only minor changes were observed. Blood pressure decreased at peak exercise from the resting value of $160 / 105$ to $155 / 90 \mathrm{mmHg}$, while heart rate increased from 60 to $72 \mathrm{bpm}$. The control group showed a marked increase in plasma catecholamines, blood pressure and heart rate.

Exercise-induced changes in beta-adrenoceptor density are shown in Table 2 . In controls beta-adrenoceptor number increased from the resting value of $17.2 \pm 4.7$ to $24.4 \pm 10.3$ $(\mathrm{p}<0.05)$ at peak exercise and continued to increase during recovery. On the contrary, in the patient beta-adrenoceptor density was $28.8 \mathrm{fmol} / \mathrm{mg}$ protein and $20.1 \mathrm{fmol} / \mathrm{mg}$ protein at peak exercise, with only minor changes during recovery.

The effects of isoproterenol infusion are shown in Table 3. In normals, isoproterenol infusion increased beta-adrenoceptor number from the control value of $17.2 \pm 3.1$ to $33.1 \pm 9.6$ $\mathrm{fmol} / \mathrm{mg}$ protein $(+94 \% ; \mathrm{p}<0.05)$, and heart rate from $82 \pm 9$ to $104 \pm 12$ bpm $(\mathrm{p}<0.01)$. Systolic blood pressure was $136 \pm 12$ $\mathrm{mmHg}$ under resting condition and $141 \pm 11$ at the end of infusion. Diastolic blood pressure was $85 \pm 9 \mathrm{mmHg}$ at rest and 78 \pm 8 after isoproterenol. In the patient, beta-adrenoceptor density which was $29.3 \mathrm{fmol} / \mathrm{mg}$ protein under control conditions, increased to $34.3 \mathrm{fmol} / \mathrm{mg}$ protein at the end of infusion $(+17 \%)$. The heart rate increased form 66 to $102 \mathrm{bpm}$ during infusion, while blood pressure fell from $160 / 100$ to $120 / 80$. It is noteworthy that in the patient, the resting value of beta-adrenoceptor density was about twice that observed in the control groups.

Table 1: Effect of Exercise on Plasma Catecholamines (NE = Norepinephrine; E = Epinephrine), Blood Pressure (BP) and Heart Rate (HR). ${ }^{\wedge} \mathrm{p}<0.01$ Compared with Resting Values by Analysis of Variance.

\begin{tabular}{|c|c|c|c|c|c|c|c|c|}
\hline & \multicolumn{4}{|c|}{ Normal Subjects } & \multicolumn{4}{|c|}{ Autonomic Insufficiency } \\
\hline & $\begin{array}{c}\text { NE } \\
\text { PG/ml) }\end{array}$ & $\underset{(\mathrm{pg} / \mathrm{ml})}{\mathrm{E}}$ & $\begin{array}{c}\text { BP } \\
(\mathrm{mmHg})\end{array}$ & $\underset{(\mathrm{bpm})}{\mathrm{HR}}$ & $\begin{array}{c}\mathrm{NE} \\
(\mathrm{pg} / \mathrm{ml})\end{array}$ & $\underset{(\mathrm{pg} / \mathrm{ml})}{\mathrm{E}}$ & $\begin{array}{c}\text { BP } \\
(\mathrm{mmHg})\end{array}$ & $\underset{\text { (bpm) }}{\mathbf{H R}}$ \\
\hline Rest & $126 \pm 20$ & $45 \pm 5$ & $142 \pm 16 / 86 \pm 10$ & $75 \pm 12$ & 96 & - & $160 / 105$ & 60 \\
\hline Exercise & $614 \pm 102^{\wedge}$ & $125 \pm 16^{\wedge}$ & $185 \pm 16^{\wedge} / 106 \pm 66^{\wedge}$ & $147 \pm 10^{\wedge}$ & 113 & 10 & $155 / 90$ & 72 \\
\hline Recovery 1 & $624 \pm 100^{\wedge}$ & $107 \pm 28^{\wedge}$ & $156 \pm 13^{\wedge} / 87 \pm 12^{\wedge}$ & $99 \pm 19 \wedge$ & 111 & - & $145 / 80$ & 66 \\
\hline Recovery 2 & $567 \pm 103^{\wedge}$ & $81 \pm 18^{\wedge}$ & $137 \pm 9 / 84 \pm 9$ & $84 \pm 11^{\wedge}$ & 97 & - & $150 / 90$ & 60 \\
\hline
\end{tabular}


Table 2: Exercise-induced Changes in Beta-Adrenoceptor Density (values are expressed as $\mathrm{fmol} / \mathrm{mg}$ protein). ${ }^{\wedge} \mathrm{p}<0.05 ;{ }^{*} \mathrm{p}<0.01$ Compared With Resting Values by Analysis of Variance

\begin{tabular}{llc}
\hline \hline & Normal Subjects & Autonomic Insufficiency \\
\hline Rest & $17.2 \pm 4.7$ & 28.8 \\
Exercise & $24.4 \pm 10.3^{\wedge}$ & 20.1 \\
Recovery 1 & $37.8 \pm 4.3^{*}$ & 23.1 \\
Recovery 2 & $41.3 \pm 12.9^{\wedge}$ & 25.2 \\
\hline
\end{tabular}

Based on previous experiences from our laboratory ${ }^{14-17}$ indicating that beta-adrenergic blockade prevents orthostatic hypotension in autonomic dysfunction, the patient was placed on propranolol ( $40 \mathrm{mg}$ b.i.d.), at the end of the study. Treatment, however, failed to control orthostatic hypotension. Therefore, after one month, propranolol was discontinued and dihydroergotamine was administered at dose of $10 \mathrm{mg}$ t.i.d. This treatment was effective in the prevention of postural hypotension. After one month of therapy, blood pressure was $160 / 100 \mathrm{mmHg}$ in the supine position, and $130 / 80 \mathrm{mmHg}$ on standing, thus allowing the patient to lead a normal life.

\section{DISCUSSION}

In normal subjects, an acute, marked rise in plasma catecholamines, as observed during maximal exercise, induces a relevant increase in beta-adrenoceptor density, which persists during the recovery period. ${ }^{12}$ Similar agonist-evoked acute beta-adrenoceptor changes have been observed in healthy individuals after the infusion of isoproterenol, ${ }^{18}$ a sympathomimetic amine that has a powerful action on beta-adrenoceptors and almost no action on alpha-adrenoceptors. The present study demonstrates that in pure autonomic insufficiency there is an incapacity to increase the lymphocyte beta-adrenoceptor number following acute adrenergic stimulation. Contrary to what was observed in control groups, our patient did not show a rise in beta-adrenoceptor levels with exertion. Furthermore, isoproterenol infusion increased beta-adrenoceptor density by only $17 \%$, a value markedly lower that that observed in controls. It has been claimed that the increase in beta-adrenoceptors that occurs in normal individuals after exposure to adrenergic agonists is caused by the unmasking of cryptic receptors. ${ }^{18}$ Since in patients with autonomic dysfunction lymphocyte beta-adrenoceptors are already upregulated ${ }^{8}$ as a consequence of the chronic exposure to low plasma levels of catecholamines, ${ }^{7}$ it is reasonable to expect that, in such patients, beta-adrenoceptor density may not increase following acute adrenergic stimulation. This hypothesis would explain the lack of an increase in beta-adrenoceptor number following exogenous stimulation with isoproterenol, while the insufficient increase in plasma catecholamines could con- tribute to the failed upregulation during exercise. Modifications in lymphocyte beta-adrenoceptor population reflect changes in the density and responsiveness of these receptors in extravascular target cells. ${ }^{8,18}$ Accordingly, the high resting number of betaadrenoceptors in autonomic failure, presumably responsible for the increased responsiveness to isoproterenol, may be implicated in the enhanced left ventricular contractility ${ }^{19}$ observed in such patients. Further studies should be designed to verify this hypothesis and to assess the pathophysiologic implications of the failed increase in beta-adrenoceptor density during exertion or other maneuvers of adrenergic stimulation.

\section{REFERENCES}

1. Bannister R. Introduction and classification. In: Bannister R, ed. Autonomic Failure. A Textbook of Clinical Disorders of the Autonomic Nervous System. Oxford: University Press, 1988: 1. 20.

2. Mathews MR. Assessing the peripheral ganglia in autonomic failure. In: Bannister R, ed. Autonomic Failure. A Textbook of Clinical Disorders of the Autonomic Nervous System. Oxford: University Press, 1988: 521-543.

3. Polinsky RJ. Neurotransmitter and neuropeptide function in autonomic failure. In: Bannister R, ed. Autonomic Failure. A Textbook of Clinical Disorders of the Autonomic Nervous System. Oxford: University Press, 1988: 321-347.

4. Ziegler MG, Lake CR, Kopin IJ. The sympathetic-nervous-system defect in primary orthostatic hypotension. N Engl J Med 1977; 296: 293-297.

5. Brevetti G, Bonaduce D, Rossi F, et al. Orthostatic hypotension: mechanisms and hemodynamics. Acta Neurol 1987; 42: 377 389.

6. Robertson D, Hollister AS, Carey EL, et al. Increased vascular beta-adrenoceptor response in autonomic dysfunction. J Am Coll Cardiol 1984; 3: 850-856.

7. Fraser J, Nadeau J, Robertson D, et al. Regulation of human leucocyte beta-receptors by endogenous catecholamines. Relationship of leucocyte beta-receptor density to the cardiac sensitivity to isoproterenol. J Clin Invest 1981; 67: 1777-1784.

8. Huy KKP, Connolly ME. Increased numbers of beta receptors in orthostatic hypotension due to autonomic dysfunction. N Engl J Med 1981; 304: 1473-1476.

9. Davies IB, Sudera D, Saguella G. Increased numbers of alphareceptors in sympathetic denervation supersensitivity in man. $J$ Clin Invest 1982; 69: 775-784.

10. Ibrahim MM. Localization of lesion in patients with idiopathic orthostatic hypotension Br Heart J 1975; 37: 868-872.

11. Boyum A. Isolation of mononuclear cells and granulocytes from human blood. Scand J Clin Lab Invest 1968; 21 (Suppl 97): 77. 79.

12. Brevetti G, Leone R, Caracciolo G, et al. Incremento della popolazione beta-adrenocettoriale linfocitaria in corso di esercizio fisico. Giorn It Cardiol 1990; 20: 20-23.

13. Hjemedalh P. Catecholamine measurement in plasma by liquid chromatography with electrochemical detection. Methods Enzymol 1987; 42: 521-534.

14. Brevetti G, Chiariello M, Lavecchia G, et al. Effects of propranolol in a case of orthostatic hypotension. Br Heart J 1979; 41: 245 248.

Table 3: Effect of Isoproterenol Infusion on Beta-Adrenoceptor Density (BAD), Blood Pressure (BP) and Heart Rate (HR). ${ }^{\wedge} \mathrm{p}<0.05 ;{ }^{*} \mathrm{p}<0.01$ Compared With Resting Values by T Test for Paired Samples

\begin{tabular}{|c|c|c|c|c|c|c|}
\hline & \multicolumn{3}{|c|}{ Normal Subjects } & \multicolumn{3}{|c|}{ Autonomic Insufficiency } \\
\hline & $\underset{(\mathbf{f m o l} / \mathbf{m g})}{\text { BAD }}$ & $\underset{(\mathbf{m m H g})}{\mathbf{B P}}$ & $\underset{(\mathrm{bpm})}{\mathrm{HR}}$ & $\underset{(\mathbf{f m o l} / \mathbf{m g})}{\mathbf{B A D}}$ & $\begin{array}{c}\mathbf{B P} \\
(\mathbf{m m H g})\end{array}$ & $\underset{\text { (bpm) }}{\text { HR }}$ \\
\hline Rest & $17.2 \pm 3.1$ & $136 \pm 12 / 85 \pm 9$ & $82 \pm 9$ & 29.3 & $160 / 100$ & 66 \\
\hline Isoproterenol & $33.1 \pm 9.6^{\wedge}$ & $141 \pm 11 / 79 \pm 8$ & $104 \pm 12^{*}$ & 34.3 & $120 / 80$ & 102 \\
\hline
\end{tabular}


15. Brevetti G, Chiariello M, Giudice P, et al. Effective treatment of orthostatic hypotension by propranolol in the Shy-Drager syndrome. Am Heart J 1981; 102: 938-941.

16. Chiariello M, Brevetti G, Bonaduce D, et al. Orthostatic hypotension due to autonomic dysfunction - different therapeutic effects of propranolol. Int J Cardiol 1983; 4: 455-462.

17. Brevetti G, Chiariello M, Bonaduce D, et al. 24-hour blood pressure recording in patients with orthostatic hypotension. Clin Cardiol 1985; 8: 406-412.
18. Tohmeh JF, Cryer PE. Biphasic adrenergic modulation of beta adrenoceptors in man. Agonist-induced early increment and late decrement in beta adrenoceptor number. J Clin Invest 1980; 65: 836-840.

19. Kronenberg MW, Forman MB, Onrot J, et al. Enhanced left ventricular contractility in autonomic failure: assessment using pressure-volume relations. J Am Coll Cardiol 1990; 15: 1334-1442. 